\title{
Genetic rescue of nonclassical ER $\alpha$ signaling normalizes energy balance in obese Ero-null mutant mice
}

\author{
Cheryl J. Park, ${ }^{1}$ Zhen Zhao, ${ }^{1}$ Christine Glidewell-Kenney, ${ }^{2}$ Milos Lazic, ${ }^{2}$ \\ Pierre Chambon, ${ }^{3}$ Andrée Krust, ${ }^{3}$ Jeffrey Weiss, ${ }^{2}$ Deborah J. Clegg, ${ }^{4}$ \\ Andrea Dunaif, ${ }^{2}$ J. Larry Jameson, ${ }^{2}$ and Jon E. Levine ${ }^{1}$
}

\begin{abstract}
1Department of Neurobiology and Physiology, Northwestern University, Evanston, Illinois, USA. '2Division of Endocrinology, Metabolism, and Molecular Medicine, Northwestern University Feinberg School of Medicine, Chicago, Illinois, USA. ${ }^{3}$ Institut de Génétique et de Biologie Moléculaire et Cellulaire, Illkirch, France. ${ }^{4}$ Department of Internal Medicine, UT Southwestern Medical Center, Dallas, Texas, USA.
\end{abstract}

\begin{abstract}
In addition to its role in reproduction, estradiol-17 $\beta$ is critical to the regulation of energy balance and body weight. Estrogen receptor $\alpha$-null $\left(E r \alpha^{-/}\right)$mutant mice develop an obese state characterized by decreased energy expenditure, decreased locomotion, increased adiposity, altered glucose homeostasis, and hyperleptinemia. Such features are reminiscent of the propensity of postmenopausal women to develop obesity and type 2 diabetes. The mechanisms by which ER $\alpha$ signaling maintains normal energy balance, however, have remained unclear. Here we used knockin mice that express mutant ER $\alpha$ that can only signal through the noncanonical pathway to assess the role of nonclassical ER $\alpha$ signaling in energy homeostasis. In these mice, we found that nonclassical ER $\alpha$ signaling restored metabolic parameters dysregulated in $E r \alpha^{-/-}$mutant mice to normal or near-normal values. The rescue of body weight and metabolic function by nonclassical ER $\alpha$ signaling was mediated by normalization of energy expenditure, including voluntary locomotor activity. These findings indicate that nonclassical $\mathrm{ER} \alpha$ signaling mediates major effects of estradiol-17 $\beta$ on energy balance, raising the possibility that selective $\mathrm{ER} \alpha$ agonists may be developed to reduce the risks of obesity and metabolic disturbances in postmenopausal women.
\end{abstract}

\section{Introduction}

In addition to its critical functions as a reproductive hormone, estradiol-17 $\beta\left(\mathrm{E}_{2}\right)$ plays a vital role in the regulation of energy balance and body weight (1). Estrogen deficiency at menopause is associated with an increased probability of obesity as well as increased risk for the development of type 2 diabetes (2). In experimental animals, reduction of circulating estrogen levels by ovariectomy leads to the development of obesity, which can be reversed or prevented by $E_{2}$ treatment (1). The effects of $E_{2}$ on energy balance bear many similarities to the actions of leptin and insulin, key molecules involved in energy homeostasis $(3,4)$. Genetic and pharmacological studies have demonstrated that leptin and insulin act directly on neural networks to modulate energy homeostasis, where the net effect is to decrease food intake and increase energy expenditure (5-9). Both can activate STAT3 in various tissues, and hypothalamic leptin and insulin signaling are known to converge on the PI3K pathway (10-13). Similarly, $\mathrm{E}_{2}$ is now also known to activate STAT3 as well as PI3K signaling cascades, suggestive of possible cross-talk among these molecules and possibly representing a common neuronal signaling mechanism that may help explain the similarities in their central effects on energy homeostasis (14-17).

That these metabolic actions of $\mathrm{E}_{2}$ are mediated by estrogen receptor $\alpha(\mathrm{ER} \alpha)$ has been demonstrated in $E r \alpha$-null $\left(E r \alpha^{-/}\right)$mutant mice, in which the ablation of ER $\alpha$ signaling results in a metabolic syndrome characterized by increased body weight, adiposity, altered glucose homeostasis, decreased energy expenditure, hyperinsulinemia, and hyperleptinemia (18-20). However, these metabolic character-

Conflict of interest: The authors have declared that no conflict of interest exists. Citation for this article: J Clin Invest. 2011;121(2):604-612. doi:10.1172/JCI41702. istics of $E r \alpha^{-/-}$mutant mice are not evident in $\operatorname{Er}^{-/-}$mutant mice, which confirms that the Er $\alpha$ isoform mediates most of the effects of $\mathrm{E}_{2}$ on energy balance. Moreover, in vivo ER $\alpha$ gene silencing in the ventromedial nucleus $(\mathrm{VMN})$ of the hypothalamus has revealed this region to be a critical locus of $\mathrm{E}_{2}$ regulation of energy balance $(21,22)$. In sum, the effects of $\mathrm{E}_{2}$ on energy homeostasis appear to require activation of the ER $\alpha$ isoform in hypothalamic neurons.

Although the role of ER $\alpha$ in $\mathrm{E}_{2}$ regulation of energy homeostasis and protection against high-fat diet-induced (HFD-induced) obesity are well documented, much less is known about the cellular signaling pathways through which ER $\alpha$ mediates its metabolic effects. In the classical $E R \alpha$ signaling pathway, $E_{2}$ binds to $E R \alpha$, inducing conformational changes that permit recruitment of coactivator or corepressor molecules and binding to estrogen response element (ERE) to regulate transcription of target genes. Whereas $\mathrm{E}_{2}$ acts predominantly through this pathway, emerging evidence supports the importance of nonclassical ER $\alpha$ signaling pathways in mediating estrogen actions. These operate independently of receptor binding directly to EREs and culminate in both genotropic and nongenotropic effects in target cells. Nonclassical genotropic ER $\alpha$ signaling includes protein-protein interactions with other transcription factors, such as activator protein-1 (AP1), specificity protein-1(SP1), and NF- $\mathrm{B}$ (23-26), which in turn mediate transcriptional regulation at their cognate response elements. Nonclassical ER $\alpha$ signaling also includes mechanisms in which cytoplasmic or membrane-associated receptor activation is coupled to stimulation of cytoplasmic signaling pathways, including the PI3K, MAPK, and cAMP-response element binding protein (CREB) signaling cascades (27-29). The extent to which $\mathrm{E}_{2}$ regulates energy homeostasis via these nonclassical ER $\alpha$ signaling pathways remains unclear. 
In the present study, we used our recently generated gene knockin mouse, which we believe to be novel, to distinguish the relative contributions of classical versus nonclassical ER $\alpha$ mechanisms in a physiological context. In these mice, an AA mutant allele (E207A/ G208A; referred to herein as AA), a mutant form of Era with disrupted classical (ERE-dependent) but intact nonclassical (EREindependent) ER $\alpha$ signaling capacities, was introduced onto the $\mathrm{Er}^{-/-}$mutant background. Initial characterization of the reproductive phenotype in these nonclassical Er $\alpha$-knockin $\left(E r \alpha^{-/ A A}\right)$ mutant mice revealed hypoplastic mammary glands, anovulation, and altered steroidogenesis (30). Certain reproductive parameters dysregulated in the $E r \alpha^{-/-}$mice, however, were restored to normal or near-normal values in the $E r \alpha^{-/ A A}$ mice, including $E_{2}$ feedback inhibition of luteinizing hormone (31).

In this study, we examined the metabolic characteristics of female $E r \alpha^{-/ A A}$ mice to test the hypothesis that nonclassical ER $\alpha$ signaling pathways mediate regulation of energy balance by $E_{2}$. We reasoned that the rescue of normal energy balance, or at least the normalization of any individual metabolic parameters that are dysregulated in $\mathrm{Era}^{-/-}$mice, would provide in vivo evidence that nonclassical ER $\alpha$ signaling pathways mediate the effects of $E_{2}$ on energy homeostasis. We additionally assessed whether alterations in energy balance in $E r \alpha^{-/-}$mice and any rescue of normal energy homeostasis in $E r \alpha^{-/ A A}$ mice are associated with corresponding changes in the $\mathrm{E}_{2}$-sensitive signaling pathways.

\section{Results}

Body weight, adiposity, and food intake. We measured the body weights of wild-type $\left(E r \alpha^{+/+}\right), E r \alpha^{-/-}$, and $E r \alpha^{-/ A A}$ female mice over a 25-week period (Figure 1, A and B). The body weights of $\mathrm{Era}^{-/-}$females were significantly higher compared with $E r \alpha^{+/+}$and $E r \alpha^{-/ A A}$ females beginning at week $8(P<0.05)$ and remained so until the end of the study. Using whole-body MRI scan, we measured percent body fat and percent lean mass in adult females and found significantly higher percent body fat in $E r \alpha^{-/-}$compared with $E r \alpha^{+/+}$and $E r \alpha^{-/ A A}$ mice $\left(E r \alpha^{-/-}, 35.4 \% \pm 2.2 \% ; E r \alpha^{+/+}, 18.5 \% \pm 2.2 \%, P<0.001 ; E r \alpha^{-/ A A}\right.$, $24.4 \% \pm 2.7 \%, P<0.01$; Figure 1C). Percent lean mass was lowest for $E r \alpha^{-/-}$compared with $E r \alpha^{+/+}$and $E r \alpha^{-/ A A}$ animals $\left(E r \alpha^{-/-}, 53.3 \% \pm 2.0 \%\right.$; $E r \alpha^{+/+}, 68.9 \% \pm 1.9 \%, P<0.001 ; E_{r \alpha}{ }^{-/ A A}, 61.5 \% \pm 2.4 \%, P<0.05$; Figure 1D). The percentages of body fat and lean mass were not significantly different across the 3 genotypes in mice that were 3-6 weeks old (data not shown).

Despite the significantly higher body weight and adiposity in $\mathrm{Er}^{-/-}$ compared with $E r \alpha^{+/+}$and $E r \alpha^{-/ A A}$ females beginning at week 8, there was no effect of genotype on food intake among the 3 groups $\left(E r \alpha^{+/+}, 11.56 \pm 0.38 \mathrm{kcal} / \mathrm{d} ; E r \alpha^{-/-}, 11.23 \pm 0.68 \mathrm{kcal} / \mathrm{d} ; E r \alpha^{-/ A A}\right.$, $10.91 \pm 0.51 \mathrm{kcal} / \mathrm{d}$; Figure $1 \mathrm{E})$. To test the possibility that differences in food intake may have been present prior to the observed differences in body weight, daily food intake was measured in mice beginning at weaning and lasting for a period of 3 weeks. As in the older mice, there was no difference in daily food intake among $E r \mathrm{C}^{+/+}, \mathrm{ErO}^{-/-}$, and $E r \alpha^{-/ A A}$ females between 3 and 6 weeks of age (data not shown). Placing the mice on a $45 \%$ HFD also did not result in differences in food intake across the 3 genotypes $\left(E r \alpha^{+/+}, 10.78 \pm 0.52 \mathrm{kcal} / \mathrm{d}\right.$; $E r \alpha^{-/-}, 11.36 \pm 0.64 \mathrm{kcal} / \mathrm{d} ; E r \alpha^{-/ A A}, 10.89 \pm 0.22 \mathrm{kcal} / \mathrm{d}$; Figure $\left.1 \mathrm{~F}\right)$; however, $E r \alpha^{-/-}$mice gained more weight on HFD than on regular chow diet (RCD) during the same period $(P<0.05$; Figure $1 G)$.

Glucose and insulin tolerance tests. Fasting blood glucose concentrations did not differ significantly in $E r \alpha^{+/+}, E r \alpha^{-/-}$, and $E r \alpha^{-/ A A}$ mice. However, blood glucose concentrations in response to glu- cose challenges in both unanesthetized and anesthetized mice were significantly elevated in $E r \alpha^{-/-}$mice compared with their $E r \alpha^{+/+}$littermates, and this difference persisted at 120 minutes after glucose injection $(P<0.001$; Figure $1 \mathrm{H}$, data shown for anesthetized mice). The blood glucose concentrations of $E r \alpha^{-/ A A}$ mice were indistinguishable from those of $E r \alpha^{+/+}$mice at all time points. Blood glucose concentration in response to insulin administration was significantly elevated in $E r \alpha^{-/-}$mice compared with their $E r \alpha^{+/+}$and $E r \alpha^{-/ A A}$ littermates at 15 minutes after insulin injection $(P<0.01$; Figure 1I).

Akt phosphorylation in response to insulin administration. The effects of insulin on phosphorylated Akt (pAkt) expression in the soleus muscle of $E r \alpha^{+/+}, E r \alpha^{-/-}$, and $E r \alpha^{-/ A A}$ mice were assessed by Western blot analyses. A significant decrease in the pAkt/Akt ratio was observed in $\mathrm{Era}^{-/-}$compared with $\mathrm{Era}^{+/+}$mice within 15 minutes of acute insulin treatment (Er $\alpha^{-/-}, 184 \% \pm 26 \%$; $E r \alpha^{+/+}, 259 \% \pm 24 \%$, $P<0.05$; Figure 1J), indicating a significant decrease in insulin action in $E r \alpha^{-/-}$mice. This effect was partially restored to normal levels in $E r \alpha^{-/ A A}$ mice $(230 \% \pm 10 \%)$. There were no significant differences in the pAkt/Akt ratio in the baseline saline-treated animals or in the total Akt level in any group.

Serum leptin levels. We examined another metabolic phenotype commonly associated with the obese state: hyperleptinemia $(32,33)$. Our measurements of basal serum leptin concentration after an overnight fast revealed significantly higher serum leptin concentrations in $E r \alpha^{-/-}$mice compared with $E r \alpha^{+/+}$and $E r \alpha^{-/ A A}$ mice $\left(E r \alpha^{-/-}, 29.13 \pm 1.87 \mathrm{ng} / \mathrm{ml} ; E r \alpha^{+/+}, 8.26 \pm 2.06 \mathrm{ng} / \mathrm{ml}, P<0.01\right.$; $E r \alpha^{-/ A A}, 14.90 \pm 2.37 \mathrm{ng} / \mathrm{ml}, P<0.01$; Figure $\left.1 \mathrm{~K}\right)$.

Locomotor activity and energy expenditure. To determine the level of locomotor activity, running-wheel behavior was measured. Figure 2A shows representative actograms and total activity counts for each genotype. During the light/inactive phase, total activity counts were not significantly different across the 3 genotypes. During the dark/active phase, however, the mean number of revolutions recorded for $E r \alpha^{-/-}$mice was 55\% lower than that for $E r \alpha^{+/+}$ animals $\left(E r \alpha^{-/-}, 12.3 \times 10^{3}\right.$ revolutions $/ 12$ hours; $E r \alpha^{+/+}, 27.4 \times 10^{3}$ revolutions $/ 12$ hours, $P<0.05$; Figure $2 \mathrm{~B}$ ). In contrast, the $E r \alpha^{-/ A A}$ females' mean wheel-running activity was restored to $90 \%$ of wildtype levels $\left(24.1 \times 10^{3}\right.$ revolutions/12 hours). Additional measurements of wheel-running activity in young mice (4-6 weeks old), made prior to the onset of significant differences in body weight, revealed similar results: total activity counts were substantially lower in $E r \alpha^{-/-}$than in $E r \alpha^{+/+}$and $E r \alpha^{-/ A A}$ mice (data not shown). To assess energy expenditure, the animals were monitored in open-circuit indirect calorimetry cages. Female $\mathrm{Era}^{-/-}$mice exhibited significantly decreased volume of oxygen consumption $\left(\mathrm{VO}_{2}\right)$ compared with $E r \alpha^{+/+}$mice $\left(E r \alpha^{-/-}, 69.76 \pm 0.51 \mathrm{ml} / \mathrm{min} / \mathrm{kg}^{0.75}\right.$; $E r \alpha^{+/+}, 78.88 \pm 0.49 \mathrm{ml} / \mathrm{min} / \mathrm{kg}^{0.75}, P<0.01$; Figure $\left.2 \mathrm{C}\right)$. In contrast, $\mathrm{VO}_{2}$ in $E r \alpha^{-/ A A}$ mice did not differ from wild-type levels $\left(76.41 \pm 0.83 \mathrm{ml} / \mathrm{min} / \mathrm{kg}^{0.75}\right)$. Consistent with results obtained from wheel-running activity in young mice, $\mathrm{VO}_{2}$ was lower in young $E r \alpha^{-/-}$mice than in young $E r \alpha^{+/+}$mice $(P<0.05$; Figure 2D).

$S T A T 3$ phosphorylation in response to $E_{2}$ and leptin administration. STAT3 phosphorylation levels were measured in the medial basal hypothalamus (MBH) after estradiol benzoate (EB) or leptin treatment in ovariectomized $\mathrm{Er}^{+/ /+}$mice by Western blot analysis. Whereas leptin rapidly and strongly induced STAT3 phosphorylation, EB treatment was without effect (Figure 3A). The absence of STAT3 activation by EB was also observed in a peroxidase immunocytochemical study like the one described below for leptin (data not shown). 
A
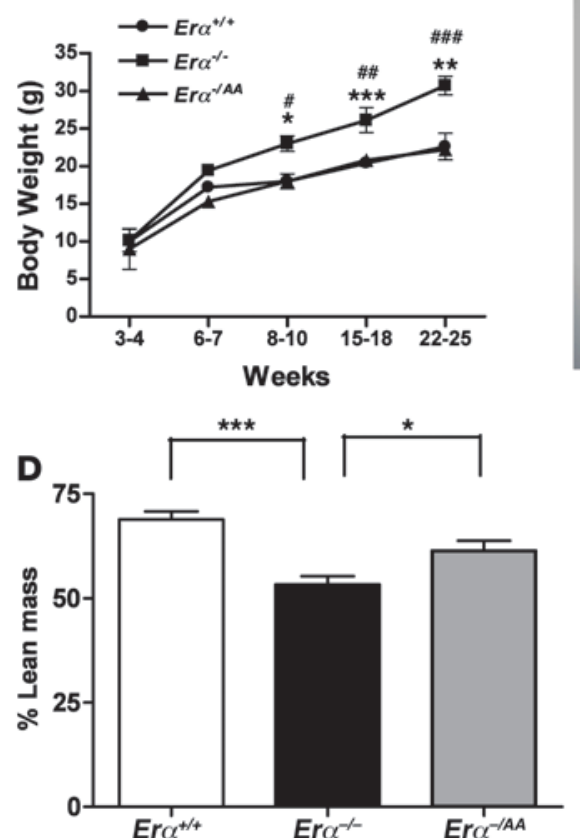

G

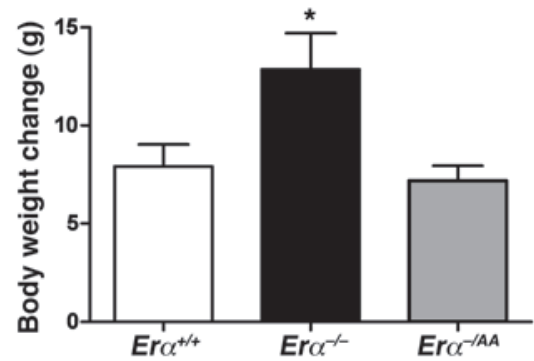

J pakt

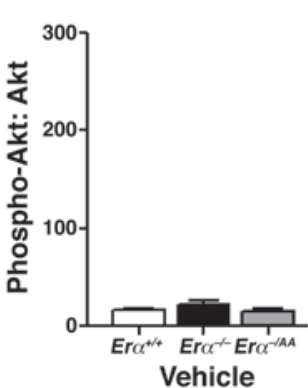

B

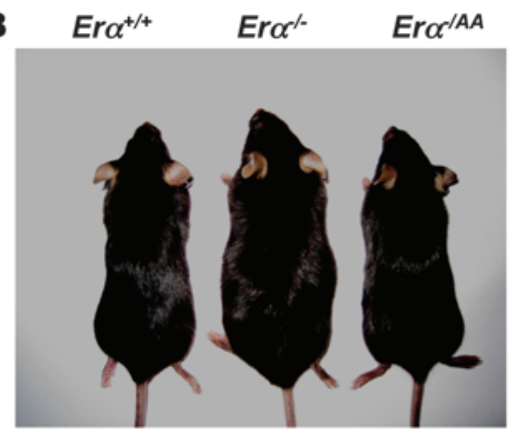

E

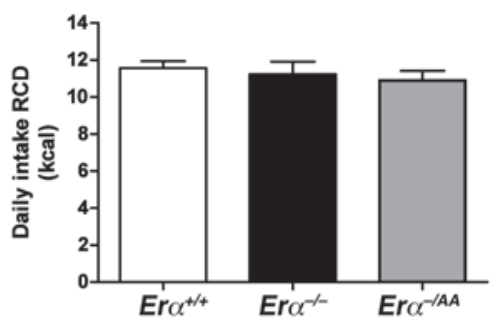

H

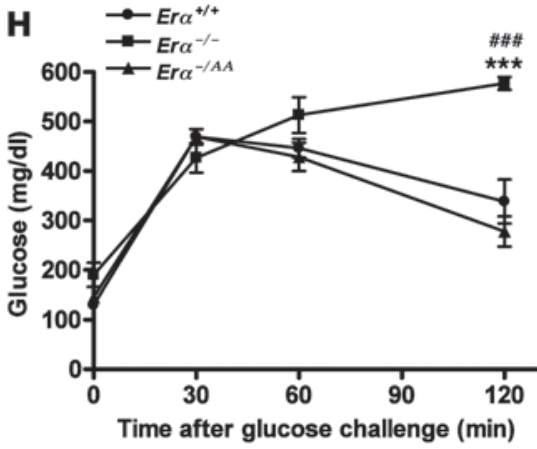

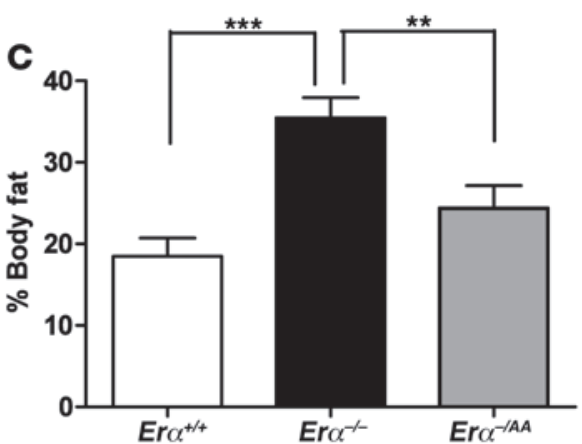

$\mathbf{F}$
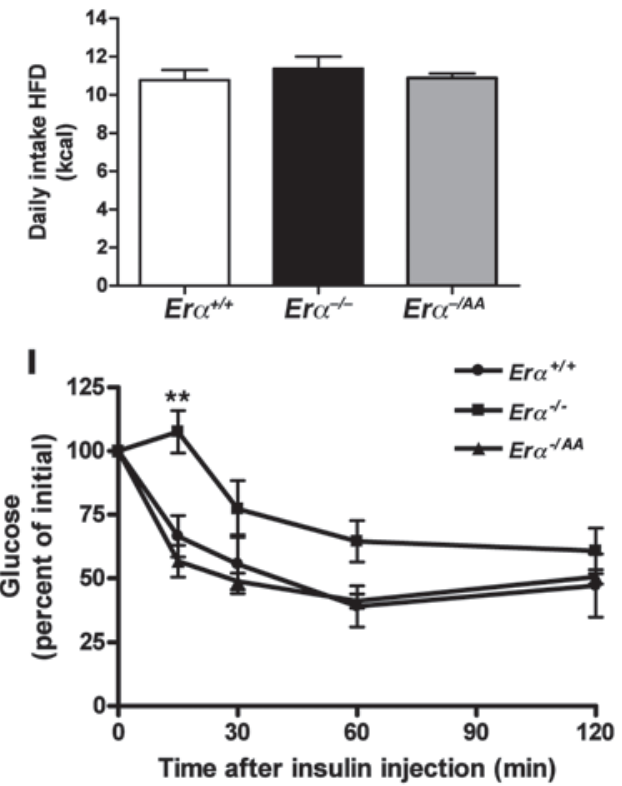

K
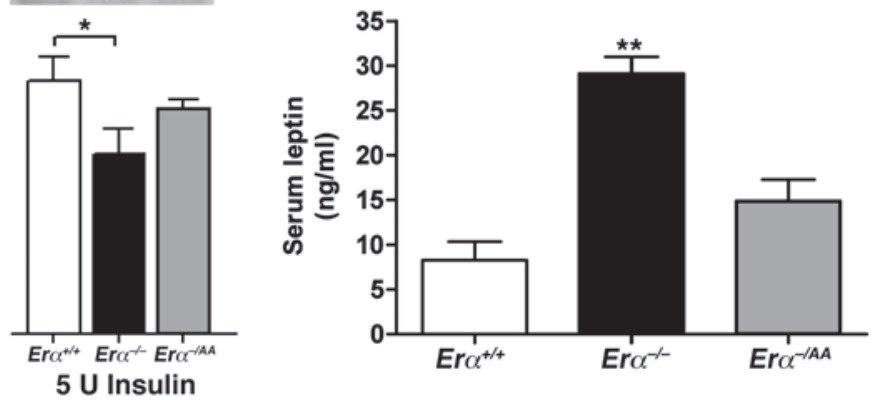

Figure 1

Nonclassical ER $\alpha$ signaling restores body weight and adiposity in $E r \alpha^{-/-}$mice to wild-type levels. (A) Body weight measurements of $E r \alpha^{+/+}$, $E r \alpha^{-1-}$, and $E r \alpha^{-/ A A}$ female mice over a 25-week period beginning at weaning revealed a significant increase in $E r \alpha^{-/-}$body weight by week 8

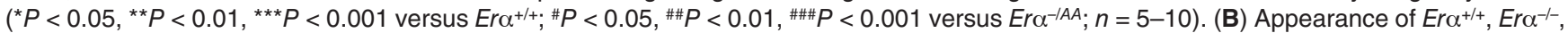
and $E r \alpha^{-/ A A}$ mice. (C) NMR imaging revealed higher percent body fat in $E r \alpha^{-/-}$mice $\left({ }^{* \star} P<0.01,{ }^{* *} P<0.001 ; n=7-11\right)$. (D) Percent lean mass was significantly lower in $E r \alpha^{-/}$mice $\left({ }^{\star} P<0.05,{ }^{* \star \star} P<0.001 ; n=7-11\right)$. (E) Daily food intake on RCD $(P=0.69 ; n=8-10)$. (F) Daily food intake on HFD $(P=0.67 ; n=8-10)$. (G) Body weight gain during HFD was significantly greater in Er $\alpha^{-/-}$mice than in Er $\alpha^{+/+}$and $E r \alpha^{-/ A A}$ mice $\left({ }^{\star} P<0.05\right.$; $n=8-10)$. (H) Blood glucose concentrations after glucose challenge in anesthetized mice ${ }^{* * \star} P<0.001$ versus Er $\alpha^{+/+;}$; \#\#P<0.001 versus Er $\alpha^{-/ A A}$; $n=6-10)$. (I) Blood glucose concentrations after insulin injection $\left.{ }^{* \star} P<0.01 ; n=6-10\right)$. (J) Effect of insulin on pAkt expression in soleus muscle ( $\left.{ }^{\star} P<0.05 ; n=6-8\right)$. (K) Serum leptin concentration ( ${ }^{* \star} P<0.01$ versus $E r \alpha^{+/+}$and $\left.E r \alpha^{-/ A A} ; n=6-10\right)$. 
A
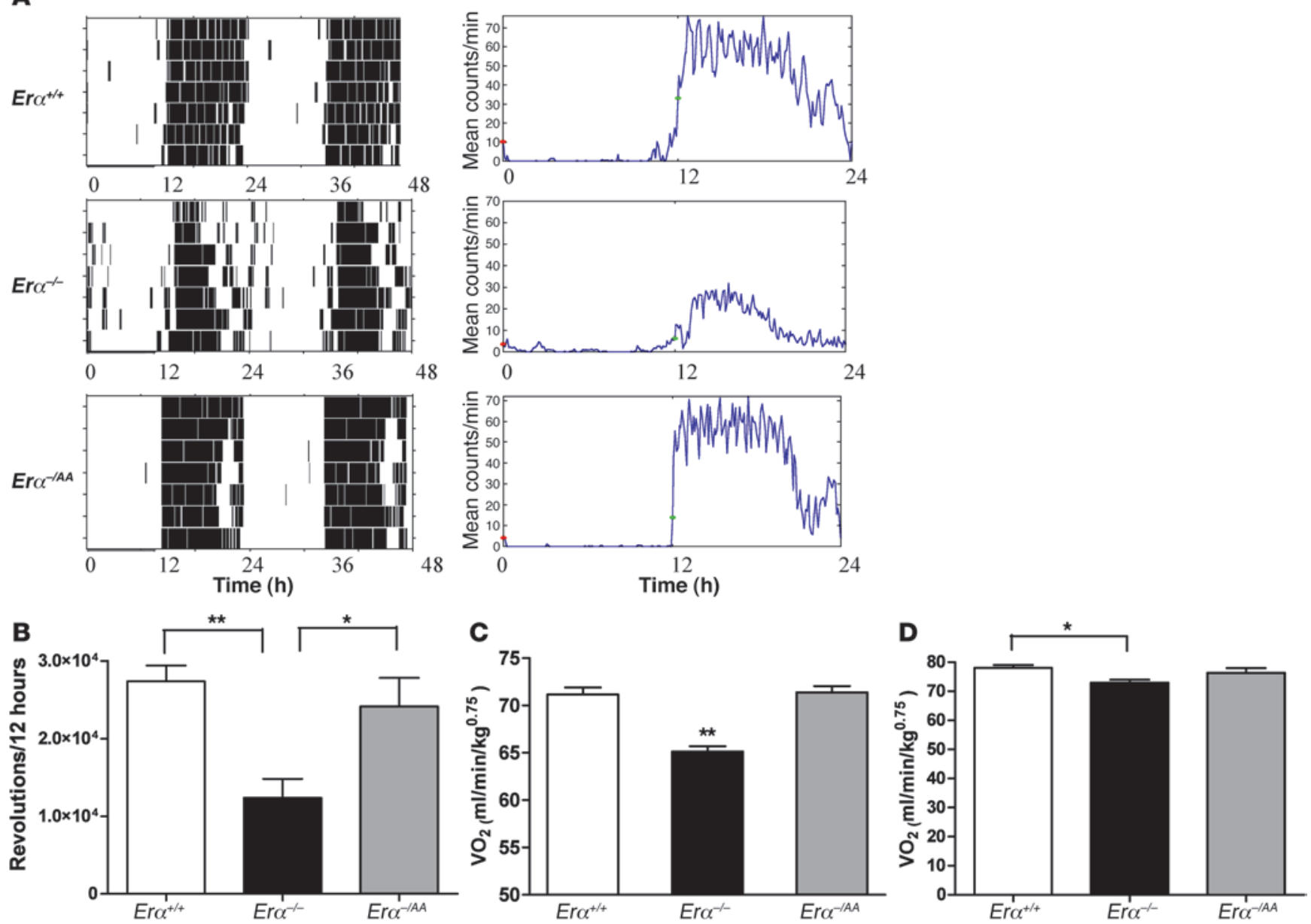

\section{Figure 2}

During the dark phase, wheel-running activity and $\mathrm{VO}_{2}$ are restored to wild-type levels in nonclassical $E r \alpha^{-/ A A}$ mutants. (A) Representative actograms and activity count plots of $E r \alpha^{+/+}$, Era ${ }^{-/-}$, and $E r \alpha^{-/ A A}$ mice. (B) Total activity counts of $E r \alpha^{-/-}$mice were approximately 3.5-fold lower than those of $E r \alpha^{+/+}$mice. In contrast, $E r \alpha^{-/ A A}$ females' wheel-running activity was restored to approximately $90 \%$ of wild-type levels $\left({ }^{\star} P<0.05,{ }^{* \star} P<0.01 ; n=6-7\right)$. (C) $E r \alpha^{-/-}$mice exhibited significantly lower $\mathrm{VO}_{2}$ compared with $E r \alpha^{+/+}$mice. In contrast, $\mathrm{VO}_{2}$ in $E r \alpha^{-/ A A}$ mice did not differ from wild-type levels $\left({ }^{\star \star} P<0.01\right.$ versus $E r \alpha^{+/+}$and $\left.E r \alpha^{-/ A A} ; n=4-6\right)$. (D) Young $E r \alpha^{-/-}$mice exhibited significantly lower $\mathrm{VO}_{2}$ than did $E r \alpha^{+/+}$mice $\left({ }^{\star} P<0.05 ; n=3-6\right)$.

STAT3 phosphorylation in response to leptin administration. The effects of leptin on pSTAT3 expression in the arcuate nucleus (ARC) of $E r \alpha^{+/+}, E r \alpha^{-/-}$, and $E r \alpha^{-/ A A}$ mice were assessed by peroxidase immunohistochemical analyses. Representative photomicrographs of pSTAT3-immunoreactive (pSTAT3-ir) cells in the ARC are provided in Figure 3B. In Era ${ }^{+/+}$mice, leptin induced a robust increase in STAT3 phosphorylation ( $84 \pm 3$ pSTAT3-ir cells/section; Figure 3C). In contrast, induction of STAT3 phosphorylation by leptin decreased to less than $20 \%$ of wild-type levels in Era ${ }^{-/-}$ mice (16 \pm 4 pSTAT3-ir cells/section, $P<0.001)$. In $E r \alpha^{-/ A A}$ mice, however, it was restored to near-normal levels (64 \pm 9 pSTAT3-ir cells/section). There were no differences in the number of PSTAT3ir cells in the ARC of the vehicle-treated groups $\left(E r \alpha^{+/+}, 2.1 \pm 1.4\right.$ pSTAT3-ir cells/section; Er $^{-/}{ }^{-}, 3.7 \pm 2.2$ pSTAT3-ir cells/section; $E r \alpha^{-/ A A}, 4.3 \pm 1.7$ pSTAT3-ir cells/section).

Additional measurements were made in young lean mice (4-6 weeks old), prior to the onset of body weight differences. There were no differences in the number of PSTAT3-ir cells following leptin treatments across the 3 genotypes in these younger animals $\left(E r \alpha^{+/+}\right.$,
$111 \pm 5$ pSTAT3-ir cells/section; Er $\alpha^{-/-}, 98 \pm 6$ pSTAT3-ir cells/section; $E r \alpha^{-/ A A}, 107 \pm 12$ pSTAT3-ir cells/section; Figure 3D).

Akt phosphorylation in response to $E_{2}$ administration. The effects of $\mathrm{E}_{2}$ on pAkt expression in the ARC and ventrolateral VMN (vlVMN) of $E r \alpha^{+/+}, E r \alpha^{-/-}$, and $E r \alpha^{-/ A A}$ mice were assessed by peroxidase immunohistochemical analyses. EB had no effect on pAkt immunoreactivity in the ARC in any group (Figure 4, A and B). In contrast, acute $\mathrm{EB}$ treatment induced a significant increase in the number of pAkt-ir cells in the vlVMN of Era ${ }^{+/+}$mice within 1 hour compared with vehicle treatment (EB, $103.3 \pm 5$ pAkt-ir cells/section; vehicle, $77 \pm 7$ pAkt-ir cells/section, $P<0.01$; Figure $4, C$ and D). This effect was completely absent in $E r \alpha^{-/-}$mice (EB, $76 \pm 5$ pAkt-ir cells/section; vehicle, $70 \pm 6$ pAkt-ir cells/section) and was restored to near-normal levels in Er $\alpha^{-/ A A}$ mice (EB, $94 \pm 5$ pAkt-ir cells/section; vehicle, $63 \pm 6$ pAkt-ir cells/section, $P<0.05$ ).

\section{Discussion}

Disruption of ER $\alpha$ signaling in $E r \alpha^{-/-}$mutant mice produces an obese metabolic phenotype characterized by decreased energy 
A

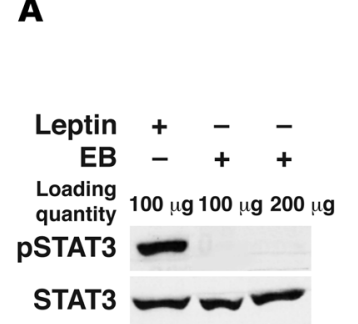

B

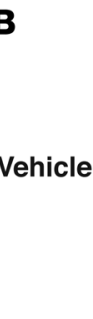

$\mathrm{Er \alpha}^{+/+}$

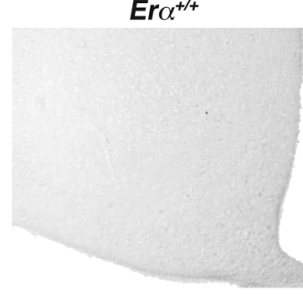

Leptin

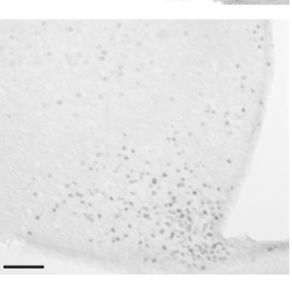

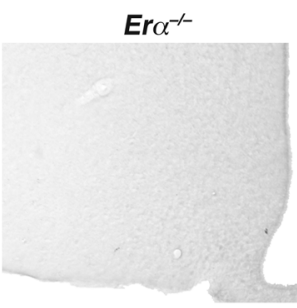
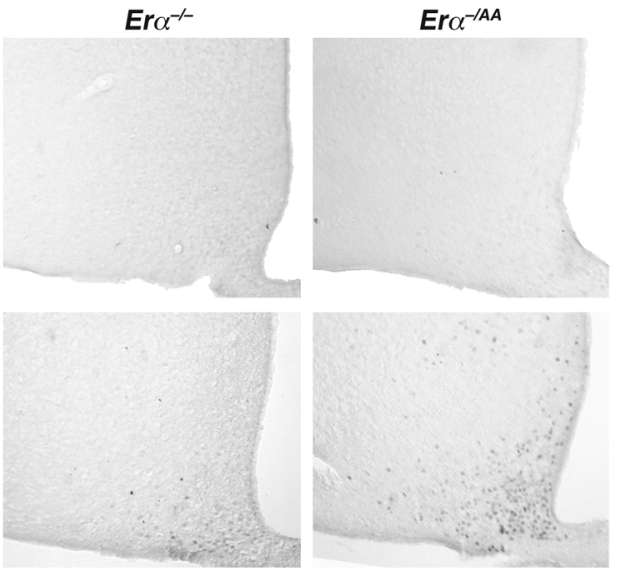

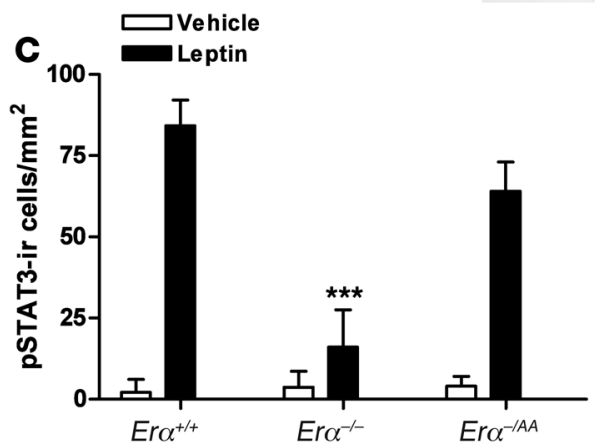

D

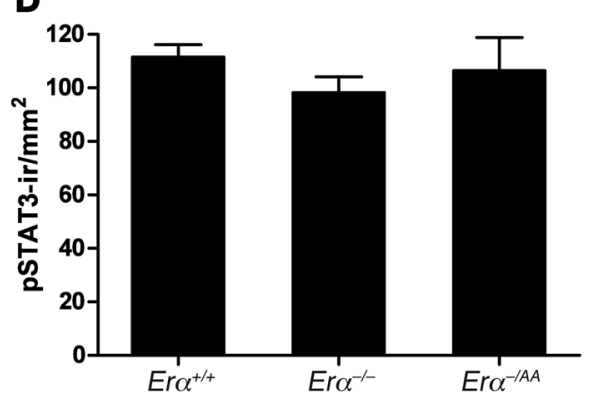

Figure 3

Leptin, but not $\mathrm{E}_{2}$, activates STAT3. (A) Representative Western blot analysis of pSTAT3 and STAT3 in MBH of Era ${ }^{+/+}$mice 30 and 60 minutes after injection with leptin and EB, respectively. (B) Representative images of leptin-induced pSTAT3 immunoreactivity in the ARC of Er $\alpha^{+/+}$, $E r \alpha^{-/-}$, and $E r \alpha^{-/ A A}$ mice 30 minutes after vehicle or leptin injection. Scale bar: $100 \mu \mathrm{m}$. (C) The number of leptin-induced pSTAT3-ir cells was significantly lower in $E r \alpha^{-/}$mice ${ }^{* * \star} P<0.001$ versus $E r \alpha^{+/+}$and $\left.E r \alpha^{-1 A A} ; n=5-8\right)$. (D) In 4- to 6-week-old $E r \alpha^{+/+}$, $E r \alpha^{-/-}$, and $E r \alpha^{-/ A A} \mathrm{mice}^{\text {, there }}$ were no differences in the number of leptin-induced pSTAT3-ir cells in the ARC $(n=4-6)$.

expenditure, but not necessarily increased energy intake $(19,20)$. Other features of metabolic syndrome are also evident in the absence of Er $\alpha$ expression, including increased visceral adiposity, hyperinsulinemia, insulin resistance, and impaired glucose tolerance (19). These metabolic characteristics of $\mathrm{Era}^{-/-}$mutant mice are not evident in $E r \beta^{-/-}$mutant mice, and they are largely phenocopied in ovariectomized animals. It is therefore generally held that the Er $\alpha$ isoform mediates most of the effects of $E_{2}$ on energy balance. The mechanisms by which ER $\alpha$ signaling normally modulates energy balance, however, have remained unclear. Here, we present evidence for a major role for nonclassical $\mathrm{ER} \alpha$ signaling in regulating energy homeostasis. We analyzed the metabolic features of $E r \alpha^{-/ A A}$ mice, which express mutant receptors that cannot signal through EREs, but retain the capability to signal through nonclassical ER $\alpha$ signaling pathways. We report that the metabolic parameters dysregulated in female $\mathrm{Er \alpha}^{-/-}$mice - body weight, adiposity, locomotor activity, energy expenditure, blood glucose levels, and serum leptin concentration - were normalized or restored to near-normal values in these $E r \alpha^{-/ A A}$ mice. These observations in $E r \alpha^{-/ A A}$ mice demonstrate that although classical ER $\alpha$ signaling may play an important role, nonclassical ER $\alpha$ signaling is sufficient to maintain the $\mathrm{E}_{2}$-sensitive physiological regulatory mechanisms that govern energy balance.

Previous studies have suggested that the major effects of ER $\alpha$ signaling on body weight occur primarily as a consequence of increases in energy expenditure, and are less dependent upon modulation of energy intake. A classic finding of Wade et al., for example, demonstrated that ovariectomy induces increases in body weight and adiposity in the absence of long-term alterations in food intake (34). Furthermore, the initial phenotypic analyses of $E r \alpha^{-/-}$mice revealed that body weights are significantly greater than in $\mathrm{Era}^{+/+}$mice beginning at approximately 3 months of age, despite similar food intake levels in the 2 groups (19). In the present study, we similarly found that $E r \alpha^{-/-}$mice weighed significantly more than their $E r \alpha^{+/+}$littermates and exhibited greater adiposity, despite the fact that their energy intake remained similar to that of $\mathrm{Era}^{+/+}$mice. Conversely, introduction of the knockin mutation was sufficient to prevent the increase in body weight to levels observed in $\mathrm{Era}^{-/-}$mice. Even when placed on a HFD, the body weight increases in $E r \alpha^{-/ A A}$ mice remained similar to those of $E r \alpha^{+/+}$mice, suggesting the involvement of nonclassical ER $\alpha$ signaling in mediating the protective effects of estrogen against HFD-induced obesity. These findings confirmed the importance of ER $\alpha$ in the regulation of body weight and revealed in vivo that nonclassical $E R \alpha$ signaling is sufficient to mediate these effects through the regulation of energy expenditure.

Although we found no evidence for altered food intake among the genotypes, previous studies have established that $\mathrm{E}_{2}$ can exert some anorectic effects in female rodents (35). Our observations suggest that any such effects may be species or paradigm specific, or, more likely, that they are mediated by signaling pathways activated via $E R \alpha$-independent mechanisms. As an example, a putative 
A
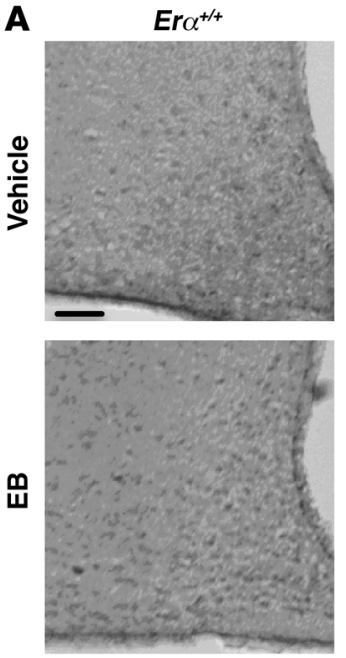

C
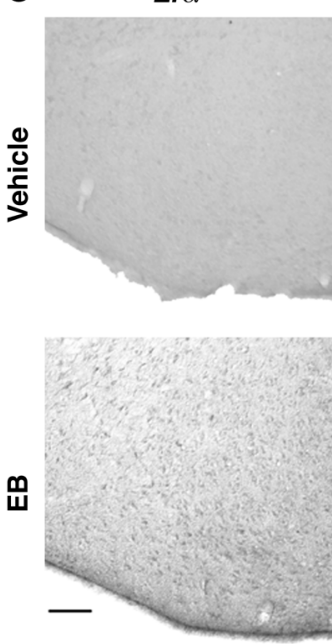

$E r \alpha^{-1-}$
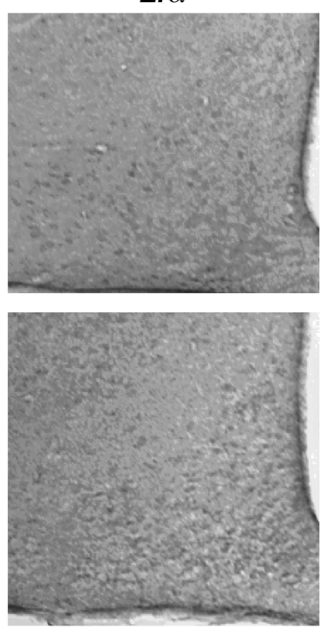

$E r \alpha^{-1-}$
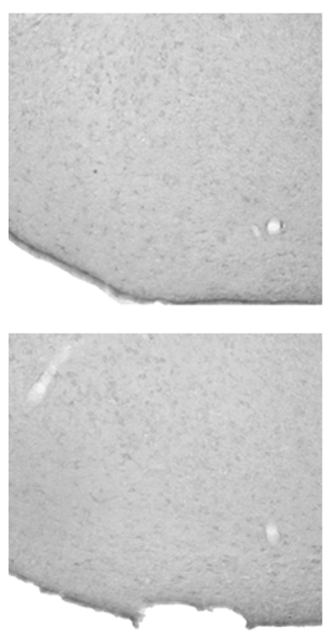

$E r \alpha^{-1 / A A}$
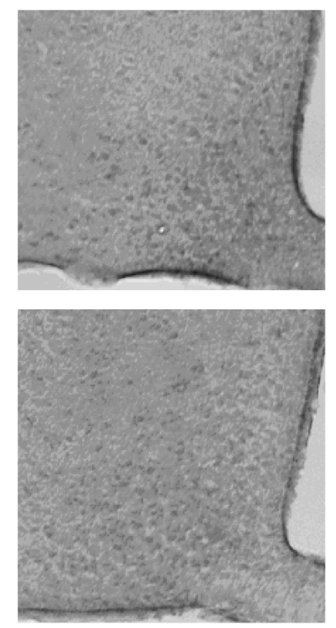

$E r \alpha^{-/ A A}$
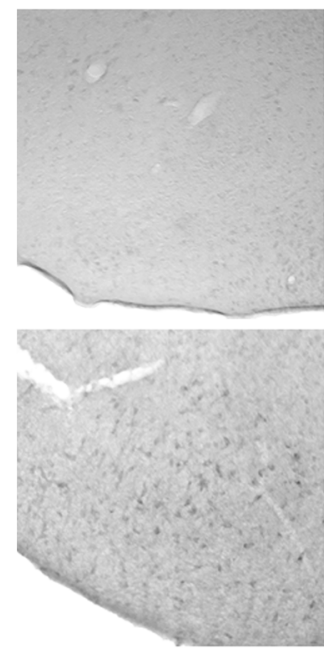

B

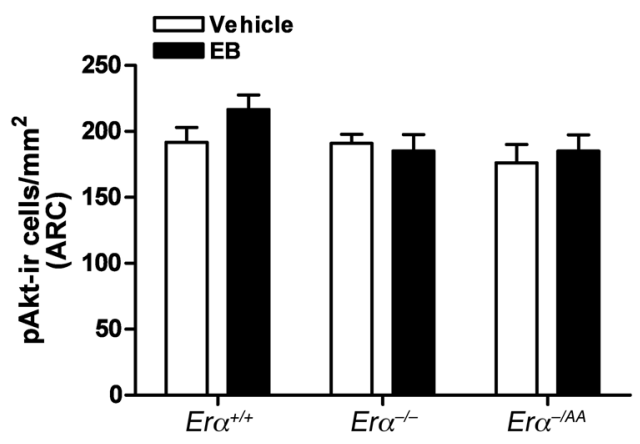

D

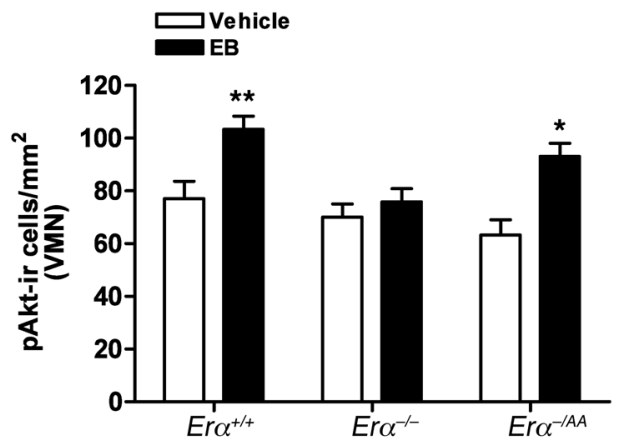

Figure 4

$E_{2}$ does not induce pAkt immunoreactivity in the ARC, but activates it in the vIVMN. (A) Representative image of EB-induced pAkt immunoreactivity in the ARC of $E r \alpha^{+/+}, E r \alpha^{-/}$, and $E r \alpha^{-/ A A}$ mice 1 hour after vehicle or EB injection. Scale bar: $100 \mu \mathrm{m}$. (B) There was no difference in the number of $\mathrm{E}_{2}$-induced pAkt-ir cells in the ARC of $\mathrm{Er \alpha}^{+/+}$, $E r \alpha^{-/}$, and $E r \alpha^{-/ A A}$ mice. (C) Representative image of $\mathrm{E}_{2}$-induced pAkt immunoreactivity in the vIVMN of $E r \alpha^{+/+}, E r \alpha^{-/-}$, and $E r \alpha^{-/ A A}$ mice 1 hour after vehicle or EB injection. Scale bar: $100 \mu \mathrm{m}$. (D) $E_{2}$ significantly increased the number of pAkt-ir cells in the vIVMN of $E r \alpha^{+/+}$and $E r \alpha^{-/ A A}$ mice, but not $E r \alpha^{-/-}$mice $\left({ }^{*} P<0.05,{ }^{* \star} P<0.01\right.$ versus vehicle; $\left.n=5-8\right)$.

membrane estrogen receptor - a Gq-coupled, membrane-initiated pathway - has been implicated in the anorectic effects of $E_{2}$ in hypoestrogenic female guinea pigs (36-38).

$E \mathrm{FO}^{-/-}$mice also exhibited a metabolic syndrome, including alterations in glucose homeostasis that were normalized in $E r \alpha^{-/ A A}$ mice. Upon glucose challenge, Era ${ }^{-/-}$mice exhibited a significant impairment of glucose tolerance compared with $\mathrm{Era}^{+/+}$animals, but nonclassical ER $\alpha$ signaling restored normal glucose sensitivity in $E r \alpha^{-/ A A}$ mice. These glucose tolerance test results were obtained in both anesthetized and awake animals, which indicates that the observed differences are not due to differences in ambient levels of physical activity. Insulin tolerance tests similarly demonstrated decreased response to insulin in $E r \alpha^{-/-}$compared with $E r \alpha^{+/+}$and $E r \alpha^{-/ A A}$ mice, indicative of insulin resistance in the obese mice that was normalized in $E r \alpha^{-/ A A}$ mice. In the soleus muscle, insulin's ability to induce Akt phosphorylation was significantly lower in $\mathrm{Era}^{-/-}$than in $\mathrm{Era}^{+/+}$mice, and par- tially rescued in $E r \alpha^{-/ A A}$ mice. Serum leptin concentrations were also significantly higher in $E r \alpha^{-/-}$than in $E r \alpha^{+/+}$mice and were restored to normal levels in $E r \alpha^{-/ A A}$ mice. These findings clearly demonstrated that nonclassical signaling can prevent the development of a metabolic syndrome that occurs in the absence of ER $\alpha$ signaling.

We also sought to determine whether alterations in physical activity and energy expenditure precede - and may therefore be determinants of - the development of obesity and metabolic syndrome in $E r \alpha^{-/-}$mice. The stimulatory effects of $\mathrm{E}_{2}$ on wheel-running activity have been well documented in mice (20). Our results similarly demonstrate that the null mutation of Er $\alpha$ produced a significant decrease in wheel-running activity, below levels observed in $\mathrm{Er}^{+/+}$ animals. In contrast, $E r \alpha^{-/ A A}$ mice exhibited activity levels comparable to those of $E r \alpha^{+/+}$animals, demonstrating that nonclassical $\mathrm{ER} \alpha$ signaling is sufficient to restore activity to normal values. Since the reduction in activity in Era ${ }^{-/-}$mice and restoration to wild-type 
levels in $E r \alpha^{-/ A A}$ mice could have been secondary to differences in body weight, wheel-running activity was measured in mice prior to the onset of significant body weight differences. The wheel-running activity in young $\mathrm{ErO}^{-/-}$mice was again significantly lower than that of young $E r \alpha^{+/+}$or $E r \alpha^{-/ A A}$ mice, which suggests that alterations in voluntary locomotor activity precede the development of obesity. Furthermore, measurements of energy expenditure revealed differences among the genotypes that paralleled those of locomotor activity. $\mathrm{VO}_{2}$ was significantly lower in $E r \alpha^{-/-}$than in $E r \alpha^{+/+}$mice, whereas $E r \alpha^{-/ A A}$ mice exhibited $\mathrm{VO}_{2}$ levels comparable to those of $E r \alpha^{+/+}$animals in both adult mice and young lean mice. Therefore, reduced energy expenditure in $E r \alpha^{-/-}$mice compared with $E r \alpha^{+/+}$and $E r \alpha^{-/ A A}$ mice, despite equivalent energy intake, appears to be a critical mechanism by which obesity develops in the Era ${ }^{-/-}$animals.

The normalization of energy balance in $E r \alpha^{-/ A A}$ mice may be caused by restoration of one or more nonclassical ER $\alpha$ signaling pathways, many of which may operate in mediobasal hypothalamic neuronal circuitries known to govern energy homeostasis. Nonclassical, genotropic responses may be elicited by tethering of ER $\alpha$ to other DNA-bound transcription factors, such as AP1, SP1, and NF- $\kappa$, to regulate transcription at their cognate response elements $(23,25,26)$. An alternative possibility is that the actions of $\mathrm{E}_{2}$ may initially be associated with common signaling pathways via the nonclassical, nongenotropic mechanism in the hypothalamus; one recent example is activation of STAT3 by $\mathrm{E}_{2}(15)$. In our study, however, $\mathrm{E}_{2}$ did not phosphorylate STAT3 in the MBH of Er $\alpha^{+/+}$mice, whereas leptin rapidly induced STAT3 phosphorylation. Further examination of leptin-induced STAT3 signaling in $E r \alpha^{+/+}, E r \alpha^{-/-}$, and $E r \alpha^{-/ A A}$ mice demonstrated activation of STAT3 by leptin in the ARC of $E r \alpha^{+/+}$and $E r \alpha^{-/ A A}$ mice, but not $E r \alpha^{-/-}$mice. Our findings suggest that nonclassical ER $\alpha$ signaling may confer STAT3 responsiveness to leptin in ARC neurons, but the mechanisms mediating this effect do not seem to involve direct activation of STAT3 by $\mathrm{E}_{2}$. Rather, leptin's ability to activate STAT3 may be secondarily influenced by ER $\alpha$-mediated alterations in metabolic status. This was confirmed by examining STAT3 phosphorylation in lean young mice, which revealed no differences in STAT3 responsiveness to leptin across genotypes.

Nonclassical, nongenotropic responses may also be initially mediated by ER $\alpha$ that is coupled to stimulation of MAPK-, CREB-, and PI3K-mediated pathways, the latter being a particularly intriguing possibility $(27,39)$ because PI3K functions as a common intracellular signaling node that mediates the neural actions of metabolic regulators such as insulin and leptin (40-42). Additionally, $\mathrm{E}_{2}$ can activate $\mathrm{PI} 3 \mathrm{~K}$ through protein-protein interactions between ER $\alpha$ and p85 (a regulatory subunit of PI3K), which in turn activate Akt in a variety of cell types, including hypothalamic neurons, a process that is completely inhibited by the PI3K inhibitors wortmannin and LY294004 $(43,44)$. We therefore tested whether $\mathrm{E}_{2}$ activates Akt via ERE-independent ER $\alpha$ signaling in $\mathrm{Era}^{+/+}$, $E r \alpha^{-/-}$, and $E r \alpha^{-/ A A}$ mice by immunocytochemistry for pAkt in the ARC and vlVMN of the hypothalamus. The ARC was a region of particular interest because of its extensive association with leptin and insulin signaling. More specifically, both leptin and insulin activated Akt in the ARC, and PI3K activity in the ARC has been linked to the regulation of energy homeostasis (10). If the effects of $E_{2}$ on energy homeostasis were achieved in part by activating Akt in the ARC, we would expect increased pAkt immunoreactivity by EB in the ARC. However, our findings did not support this hypothesis: EB did not significantly increase induction of pAkt in the ARC of $E_{r \alpha}^{+/+}, E r \alpha^{-/-}$, or $E r \alpha^{-/ A A}$ mice.
The VMN was another region of interest for the activation of Akt, as it is a critical center of energy homeostasis. Animals with lesions to the VMN exhibit hyperphagia, increased body weight, increased adiposity, and reduced energy expenditure $(45,46)$. Furthermore, when VMN-lesioned animals are pair-fed with unlesioned animals, the lesioned animals exhibit significantly reduced energy expenditure prior to the onset of body weight differences, which suggests that the VMN is an important regulator of energy use. The VMN (more specifically, the vlVMN) is also a nucleus with very high density of $\operatorname{ER} \alpha(47,48)$, and focused silencing of ER $\alpha$ in this nucleus generates a metabolic state similar to that in $\mathrm{Er}^{-/-}$mutant mice, which suggests that ER $\alpha$ in the VMN plays an essential role in control of energy balance and maintenance of normal body weight (22). We report here that $\mathrm{E}_{2}$ significantly induced activation of Akt in $\mathrm{Er}^{+/+}$mice, but not $\mathrm{Er \alpha}^{-/-}$mice, in the vlVMN, confirming the requirement of $E R \alpha$ for $E_{2}$ induction of pAkt. Furthermore, Akt activation by $\mathrm{E}_{2}$ was restored in $E r \alpha^{-/ A A}$ mice, which suggests that ERE-independent ER $\alpha$ signaling is sufficient to evoke rapid activation of Akt. This finding demonstrates that $\mathrm{E}_{2}$ can evoke nonclassical ER $\alpha$ signaling in VMN neurons and suggests at least one potential route through which nonclassical ER $\alpha$ signaling may convey some of $\mathrm{E}_{2}$ effects on energy homeostasis in the VMN.

In conclusion, our findings in the $E r \alpha^{-/ A A}$ genetic model established that nonclassical ER $\alpha$ signaling mechanisms are sufficient to transduce virtually all major effects of $\mathrm{E}_{2}$ on energy homeostasis in female mice. These findings raise the possibility that nonclassical ER $\alpha$ signaling pathways may be identifiable as new drug targets for the treatment of metabolic disorders in postmenopausal women. Different selective estrogen receptor modulators can possess agonist, antagonist, or mixed pharmacological properties that are specific to tissues, cells, target genes, and signaling pathways (49-51). Thus, treatments that selectively activate nonclassical ER $\alpha$ signaling pathways might have reduced oncogenic potential associated with classical signaling mechanisms $(52,53)$, yet retain agonistic properties that could lead to reduced risk of obesity and metabolic disturbances in women.

\section{Methods}

Animals. All animal care and use procedures were in accordance with guidelines of the Animal Care and Use Committee of Northwestern University. Mice were maintained on a 12-hour light/12-hour dark cycle and given RCD or HFD ( $45 \% \mathrm{kcal}$ from fat; Research Diets Inc.) with water available ad libitum. In the HFD study, animals were maintained on a HFD for 4 weeks. $E r \alpha^{-1-}$ and $E r \alpha^{-/ A A}$ mutant mice were generated as previously described $(30,54)$. All breeders were derived from previous backcrosses for 8-13 generations onto the C57BL/ 6 background. Compound heterozygotes $\left(E r \alpha^{-/ A A}\right)$ were generated by mating heterozygote $E r \alpha^{+/ A A}$ males with heterozygote $E r \alpha^{+/-}$females. $E r \alpha^{-/-}$mice were generated by mating $E r \alpha^{+/-}$males with $E_{r \alpha}{ }^{+/-}$females. All mice were genotyped at weaning. DNA was isolated by digestion of tail tissue and amplified in 2 separate PCRs to determine the presence or absence of the wild-type Er $\alpha$ and the presence or absence of the knockin mutation.

Body weight and food intake. Measurements of body weights were taken at 5 time points: $3-4,6-7,8-10,15-18$, and $22-25$ weeks after birth. Food intake on either RCD or HFD was measured daily at specified ages.

Body fat and lean mass determination. Body fat and lean mass were analyzed with a mouse-specific NMR apparatus (Echo MRI Whole Body Composition Analyzer; Echo Medical Systems).

Locomotor activity. Wheel-running activity was recorded for 21 consecutive days. Mice were individually housed in cages equipped with a $12.5-\mathrm{cm}$-diameter exercise wheel. Each wheel revolution triggered a microswitch mounted 
on the outside of the cage near the axle of the wheel. Data were collected using Chronobiology Kit (Stanford Software Systems), and Fast Fourier Transform Analysis was used to analyze activity data (Clocklab Actimetrics).

Energy expenditure. Indirect calorimetry was performed on individually housed mice in polycarbonate calorimeter cages. Animals were placed in cages for a 24-hour acclimation period prior to calorimetric measurements. Indirect calorimetry was performed using a computer-controlled Physioscan open-circuit calorimetry system (Accuscan Instruments). $\mathrm{VO}_{2}$ was determined as milliliters per minute per kilogram body weight $\left(\mathrm{ml} / \mathrm{min} / \mathrm{kg}^{0.75}\right)$. Calorimetric measurements were measured for each mouse at 10 -minute intervals over a 24 -hour period, beginning 4 hours prior to the onset of the dark phase.

Glucose and insulin tolerance tests. Animals were fasted for 16 and 4 hours before i.p. injection of $2 \mathrm{~g} / \mathrm{kg}$ glucose and $0.5 \mathrm{U} / \mathrm{kg}$ insulin, respectively. Blood samples were collected from the tail vein at $0,30,60$, and 120 minutes after glucose or insulin administration. Blood glucose concentration was measured using a blood glucose monitoring system (OneTouch; Johnson $\&$ Johnson). Glucose tolerance test was administered in both awake animals and in animals anesthetized with sodium pentobarbital $(50 \mathrm{mg} / \mathrm{kg})$.

Effects of insulin-Akt signaling in soleus muscle. Animals were given i.p. injection of human insulin ( $0.15 \mathrm{U} / \mathrm{g}$; Eli Lilly) after a 4-hour fast. 15 minutes after insulin injection, soleus muscles were removed and flash frozen. Muscle samples were processed as previously described (55), with minor modifications. Protein content was determined by DC protein assay (BioRad Laboratories). Soleus muscle lysates (50 $\mu$ g protein) were resolved using SDS-PAGE on $7.5 \%$ gels and immunoblotted with antibodies specific to protein kinase B (Akt) and pAkt (ser473) (Cell Signaling Technology) and appropriate secondary antibody (goat anti-rabbit horseradish peroxidase conjugates; Cell Signaling). $E r \alpha^{+/+}, E r \alpha^{-/-}$, and $E r \alpha^{-/ A A}$ samples were run together on the same gels, and signals were detected by chemiluminescence (ECL Western Blotting Detection Reagent; Amersham; refs. $55,56)$. Immunoblots were quantified using a high-resolution scanner, and density was calculated using NIH ImageJ software. The same internal standard was loaded on all immunoblots, and results were expressed as percent of internal standard. Phosphorylation was expressed as the ratio of phosphorylated to total protein $(55,56)$.

Hormone assay. Serum leptin levels were determined using RIA reagents obtained from Linco Research. The leptin assay had a lower limit of detection of $0.25 \mathrm{ng} / \mathrm{ml}$, and the intraassay and interassay coefficients of variance were $3.93 \%$ and $8.29 \%$, respectively.

Effects of EB and leptin on STAT3 phosphorylation. On the morning of day 7 after ovariectomy, animals were given a subcutaneous injection of EB $(1 \mu \mathrm{g} /$ mouse). 1 hour after injection, animals were anesthetized with i.p. injection of $75 \mathrm{mg} / \mathrm{kg}$ ketamine (Fort Dodge Laboratories) and $5 \mathrm{mg} / \mathrm{kg}$ xylazine (Burns Veterinary Supply). As control for STAT3 activity, leptin $(5 \mathrm{mg} / \mathrm{kg}$; R\&D Systems) was administered on day 7 after an overnight fast. The $\mathrm{MBH}$ was dissected and homogenized in lysis buffer $(20 \mathrm{mM}$ Tris-HCl, pH 7.4; 150 mM NaCl; 1\% Triton X-100; 0.5 mM EDTA; and proteinase inhibitors). Western blot analyses were performed according to standard protocols using antibodies against PSTAT3 and STAT3 (Cell Signaling Technology).

Effect of leptin on STAT3 phosphorylation. On day 0, mice were anesthetized and bilaterally ovariectomized. On day 6, food was removed before the start of the dark phase, and on the morning of day 7, mice were given i.p. injection of vehicle or leptin ( $5 \mathrm{mg} / \mathrm{kg}$; R\&D Systems). 30 minutes after injection, animals were anesthetized with $75 \mathrm{mg} / \mathrm{kg}$ i.p. ketamine and $5 \mathrm{mg} / \mathrm{kg}$ i.p. xylazine and transcardially perfused with $4 \%$ paraformaldehyde (Sigma-Aldrich). Brains were removed, postfixed in the perfusion solution for 12 hours, and then placed in $30 \%$ sucrose in $0.1 \mathrm{M}$ phosphate buffer until they sank. Coronal brain sections $(30 \mu \mathrm{m})$ were cut in a CM1900 cryostat (Leica) for subsequent immunostaining. Immunocytochemical procedures were performed as previously described (57). Briefly, sections were rinsed in $0.1 \mathrm{M}$ PBS for 30 minutes and pretreated with $3 \% \mathrm{H}_{2} \mathrm{O}_{2}$ in methanol for 40 minutes. After a minimum of 3 rinses in PBS, the sections were immersed in PBS with $0.3 \%$ glycine for 25 minutes. After additional rinses, sections were placed in $0.03 \%$ sodium dodecyl sulfate for 25 minutes. All sections were rinsed again and placed in $4 \%$ normal serum, $0.4 \%$ Triton X-100, and 1\% BSA for 30 minutes before incubation with PSTAT3 mouse $\mathrm{mAb}$ (Cell Signaling) for 72 hours at $4{ }^{\circ} \mathrm{C}$ in $1 \%$ normal serum, $0.4 \%$ Triton X-100, and 1\% BSA. Sections were then rinsed in PBS and incubated in biotinylated goat anti-mouse IgG diluted 1:500 for 1 hour at room temperature, followed by incubation in avidin-biotin complex (Vectastain ABC; Vector Laboratories) in PBS plus $0.4 \%$ Triton X-100 for 1 hour at room temperature. Finally, sections were incubated in 3,3'-diaminobenzidine (DAB; Vector Laboratories) for brown precipitate development at room temperature. Sections were visualized on a Nikon Eclipse TE 2000-S microscope (Nikon). To define the area of interest, the boundary of the ARC was drawn using a template derived from the Paxinos and Franklin atlas of the mouse (58), creating an enclosed area. Matched sections corresponding to anterior-posterior coordinates were selected from each brain for PSTAT3 immunocytochemical analyses. The number of PSTAT3-ir cells in the ARC was counted manually using NIH ImageJ software (version 1.63). 3 sections from ARC were selected per mouse. For each mouse, the average number of cells counted in the ARC was used for statistical comparisons.

EB treatment and immunocytochemistry for pAkt. 7 days after ovariectomy, mice were given subcutaneous injection of vehicle or EB ( $1 \mu \mathrm{g} / \mathrm{mouse})$. After 1 hour, animals were anesthetized and perfused, and their brains were fixed. Sliced sections were pretreated with $3 \% \mathrm{H}_{2} \mathrm{O}_{2}$ in PBS for 20 minutes before immersion in $0.03 \%$ sodium dodecyl sulfate in PBS for 10 minutes. After incubation in $4 \%$ normal serum and $0.4 \%$ Triton X-100 in PBS for 2 hours, sections were incubated in mouse anti-pAkt (Ser473; 1:500 dilution, Cell Signaling) in $4 \%$ normal serum and $0.4 \%$ Triton X-100 for 72 hours at $4{ }^{\circ} \mathrm{C}$. After 72 hours, sections were processed as described previously (59). Incubation without the primary antibody resulted in the absence of detectable signal. Immunocytochemical analyses were performed as described above for the PSTAT3 procedure, except that the protein of interest was pAkt and the regions of interest were the ARC and vlVMN.

Statistics. Statistical significance among groups was tested with 1-way ANOVA followed by Bonferroni post-hoc test. 2-way ANOVA followed by Bonferroni post-hoc test was used to test for significance in immunocytochemical studies. Repeated-measures ANOVA was used to analyze body weights and glucose levels of the 3 genotypes across stated time points. Data are presented as mean \pm SEM. In all analyses, a $P$ value less than 0.05 was considered statistically significant.

\section{Acknowledgments}

We thank B. Mann, C. Capshew, J. Chambers, S. Dubois, and S. Losee-Olson for excellent technical assistance. This work was supported by NIH grants awarded through the Eunice Kennedy Shriver National Institute of Child Health and Human Development and the Office of Research on Women's Health (P50 HD44405 and P01 HD21921).

Received for publication November 9, 2009, and accepted in revised form November 23, 2010.

Address correspondence to: Jon E. Levine, Department of Neurobiology and Physiology, Northwestern University, 2205 Tech Drive, Evanston, Illinois 60208, USA. Phone: 847.491.7180; Fax: 847.491.5211; E-mail: jlevine@northwestern.edu. 
1. Wade GN, Gray JM. Gonadal effects on food intake and adiposity: a metabolic hypothesis. Physiol Behav. 1979;22(3):583-593.

2. Carr MC. The emergence of the metabolic syndrome with menopause. J Clin Endocrinol Metab. 2003; 88(6):2404-2411.

3. Zhang Y, Proenca R, Maffei M, Barone M, Leopold L, Friedman JM. Positional cloning of the mouse obese gene and its human homologue. Nature. 1994; 372(6505):425-432.

4. Brief DJ, Davis JD. Reduction of food intake and body weight by chronic intraventricular insulin infusion. Brain Res Bull. 1984;12(5):571-575

5. Halaas JL, et al. Weight-reducing effects of the plasma protein encoded by the obese gene. Science. 1995;269(5223):543-546.

6. Maffei M, et al. Leptin levels in human and rodent: measurement of plasma leptin and ob RNA in obese and weight-reduced subjects. Nat Med. 1995; 1(11):1155-1161

7. Pelleymounter MA, et al. Effects of the obese gene product on body weight regulation in ob/ob mice. Science. 1995;269(5223):540-543.

8 . Bruning JC, et al. Role of brain insulin receptor in control of body weight and reproduction. Science. 2000;289(5487):2122-2125.

9. Woods SC, Lotter EC, McKay LD, Porte D Jr. Chronic intracerebroventricular infusion of insulin reduces food intake and body weight of baboons. Nature. 1979;282(5738):503-505.

10. Niswender KD, et al. Insulin activation of phosphatidylinositol 3-kinase in the hypothalamic arcuate nucleus: a key mediator of insulin-induced anorexia. Diabetes. 2003;52(2):227-231.

11. Niswender KD, Morton GJ, Stearns WH, Rhodes CJ, Myers MG Jr, Schwartz MW. Intracellular signalling. Key enzyme in leptin-induced anorexia. Nature. 2001;413(6858):794-795.

12. Niswender KD, Schwartz MW. Insulin and leptin revisited: adiposity signals with overlapping physiological and intracellular signaling capabilities. Front Neuroendocrinol. 2003;24(1):1-10.

13. Xu AW, Kaelin CB, Takeda K, Akira S, Schwartz MW, Barsh GS. PI3K integrates the action of insulin and leptin on hypothalamic neurons. J Clin Invest. 2005;115(4):951-958.

14. Gao Q, Horvath TL. Cross-talk between estrogen and leptin signaling in the hypothalamus. $A m \mathrm{~J}$ Physiol Endocrinol Metab. 2008;294(5):E817-E826.

15. Gao Q, et al. Anorectic estrogen mimics leptin's effect on the rewiring of melanocortin cells and Stat 3 signaling in obese animals. Nat Med. 2007;13(1):89-94.

16. Malyala A, Kelly MJ, Ronnekleiv OK. Estrogen modulation of hypothalamic neurons: activation of multiple signaling pathways and gene expression changes. Steroids. 2005;70(5-7):397-406

17. Malyala A, Zhang C, Bryant DN, Kelly MJ, Ronnekleiv OK. PI3K signaling effects in hypothalamic neurons mediated by estrogen. J Comp Neurol. 2008;506(6):895-911.

18. Bryzgalova G, et al. Evidence that oestrogen receptor-alpha plays an important role in the regulation of glucose homeostasis in mice: insulin sensitivity in the liver. Diabetologia. 2006;49(3):588-597.

19. Heine PA, Taylor JA, Iwamoto GA, Lubahn DB, Cooke PS. Increased adipose tissue in male and female estrogen receptor-alpha knockout mice. Proc Natl Acad Sci U S A. 2000;97(23):12729-12734.

20. Ogawa S, Chan J, Gustafsson JA, Korach KS, Pfaff DW. Estrogen increases locomotor activity in mice through estrogen receptor alpha: specificity for the type of activity. Endocrinology. 2003;144(1):230-239.

21. Yokosuka M, Okamura H, Hayashi S. Postnatal development and sex difference in neurons containing estrogen receptor-alpha immunoreactivity in the preoptic brain, the diencephalon, and the amygdala in the rat. J Comp Neurol. 1997;389(1):81-93.

22. Musatov S, et al. Silencing of estrogen receptor alpha in the ventromedial nucleus of hypothalamus leads to metabolic syndrome. Proc Natl Acad Sci US A. 2007;104(7):2501-2506.

23. Paech K, et al. Differential ligand activation of estrogen receptors ERalpha and ERbeta at AP1 sites. Science. 1997;277(5331):1508-1510.

24. Coleman KM, Smith CL. Intracellular signaling pathways: nongenomic actions of estrogens and ligand-independent activation of estrogen receptors. Front Biosci. 2001;6:D1379-D1391.

25. Porter W, Wang F, Wang W, Duan R, Safe S. Role of estrogen receptor/Sp1 complexes in estrogeninduced heat shock protein 27 gene expression. Mol Endocrinol. 1996;10(11):1371-1378.

26. Cerillo $\mathrm{G}$, et al. The oestrogen receptor regulates NFkappaB and AP-1 activity in a cell-specific manner. J Steroid Biochem Mol Biol. 1998;67(2):79-88.

27. Singh M. Ovarian hormones elicit phosphorylation of Akt and extracellular-signal regulated kinase in explants of the cerebral cortex. Endocrine. 2001;14(3):407-415.

28. Watters JJ, Campbell JS, Cunningham MJ, Krebs EG, Dorsa DM. Rapid membrane effects of steroids in neuroblastoma cells: effects of estrogen on mitogen activated protein kinase signalling cascade and c-fos immediate early gene transcription. Endocrinology. 1997;138(9):4030-4033.

29. Zhou Y, Watters JJ, Dorsa DM. Estrogen rapidly induces the phosphorylation of the cAMP response element binding protein in rat brain. Endocrinology. 1996;137(5):2163-2166.

30. Jakacka M, Ito M, Martinson F, Ishikawa T, Lee EJ, Jameson JL. An estrogen receptor (ER)alpha deoxyribonucleic acid-binding domain knock-in mutation provides evidence for nonclassical ER pathway signaling in vivo. Mol Endocrinol. 2002;16(10):2188-2201.

31. Glidewell-Kenney C, Hurley LA, Pfaff L, Weiss J, Levine JE, Jameson JL. Nonclassical estrogen receptor alpha signaling mediates negative feedback in the female mouse reproductive axis. Proc Natl Acad Sci U S A. 2007;104(19):8173-8177

32. Frederich RC, Hamann A, Anderson S, Lollmann B, Lowell BB, Flier JS. Leptin levels reflect body lipid content in mice: evidence for diet-induced resistance to leptin action. Nat Med. 1995;1(12):1311-1314.

33. Frederich RC, et al. Expression of ob mRNA and its encoded protein in rodents. Impact of nutrition and obesity. J Clin Invest. 1995;96(3):1658-1663.

34. Wade GN, Gray JM, Bartness TJ. Gonadal influences on adiposity. Int J Obes. 1985;9 suppl 1:83-92.

35 . Asarian L, Geary N. Cyclic estradiol treatment normalizes body weight and restores physiological patterns of spontaneous feeding and sexual receptivity in ovariectomized rats. Horm Behav. 2002;42(4):461-471.

36. Roepke TA, Xue C, Bosch MA, Scanlan TS, Kelly MJ, Ronnekleiv OK. Genes associated with membrane-initiated signaling of estrogen and energy homeostasis. Endocrinology. 2008;149(12):6113-6124.

37. Roepke TA. Oestrogen modulates hypothalamic control of energy homeostasis through multiple mechanisms. J Neuroendocrinol. 2009;21(2):141-150.

38. Qiu J, et al. Rapid signaling of estrogen in hypothalamic neurons involves a novel G-protein-coupled estrogen receptor that activates protein kinase C. J Neurosci. 2003;23(29):9529-9540.

39. Mannella P, Brinton RD. Estrogen receptor protein interaction with phosphatidylinositol 3kinase leads to activation of phosphorylated Akt and extracellular signal-regulated kinase $1 / 2$ in the same population of cortical neurons: a unified mechanism of estrogen action. J Neurosci. 2006; 26(37):9439-9447.

40. Morrison CD, Morton GJ, Niswender KD, Gelling RW, Schwartz MW. Leptin inhibits hypothalamic Npy and Agrp gene expression via a mechanism that requires phosphatidylinositol3-OHkinase signaling. Am J Physiol Endocrinol Metab. 2005;289(6):E1051-E1057.
41. Morton GJ, Gelling RW, Niswender KD, Morrison CD, Rhodes CJ, Schwartz MW. Leptin regulates insulin sensitivity via phosphatidylinositol-3-OH kinase signaling in mediobasal hypothalamic neurons. Cell Metab. 2005;2(6):411-420.

42. Zhao AZ, Huan JN, Gupta S, Pal R, Sahu A. A phosphatidylinositol 3-kinase phosphodiesterase 3B-cyclic AMP pathway in hypothalamic action of leptin on feeding. Nat Neurosci. 2002;5(8):727-728.

43. Cardona-Gomez GP, Mendez P, Garcia-Segura LM. Synergistic interaction of estradiol and insulin-like growth factor-I in the activation of PI3K/Akt signaling in the adult rat hypothalamus. Brain Res Mol Brain Res. 2002;107(1):80-88.

44. Titolo D, Mayer CM, Dhillon SS, Cai F, Belsham DD. Estrogen facilitates both phosphatidylinositol 3-kinase/Akt and ERK1/2 mitogen-activated protein kinase membrane signaling required for long-term neuropeptide $\mathrm{Y}$ transcriptional regulation in clonal, immortalized neurons. J Neurosci. 2008;28(25):6473-6482.

45. Vilberg TR, Keesey RE. Reduced energy expenditure after ventromedial hypothalamic lesions in female rats. Am J Physiol. 1984;247(1 pt 2):R183-R188.

46. Cox JE, Powley TL. Intragastric pair feeding fails to prevent VMH obesity or hyperinsulinemia. Am J Physiol. 1981;240(5):E566-E572.

47. Shughrue PJ, Lane MV, Merchenthaler I. Comparative distribution of estrogen receptor-alpha and -beta mRNA in the rat central nervous system. J Comp Neurol. 1997;388(4):507-525.

48. McClellan KM, Parker KL, Tobet S. Development of the ventromedial nucleus of the hypothalamus. Front Neuroendocrinol. 2006;27(2):193-209.

49. Jordan VC, Gapstur S, Morrow M. Selective estrogen receptor modulation and reduction in risk of breast cancer, osteoporosis, and coronary heart disease. J Natl Cancer Inst. 2001;93(19):1449-1457.

50. Lewis JS, Jordan VC. Selective estrogen receptor modulators (SERMs): mechanisms of anticarcinogenesis and drug resistance. Mutat Res. 2005; 591(1-2):247-263.

51. McDonnell DP, Norris JD. Connections and regulation of the human estrogen receptor. Science. 2002; 296(5573):1642-1644.

52. Fisher B, et al. Tamoxifen for prevention of breast cancer: report of the National Surgical Adjuvant Breast and Bowel Project P-1 Study. J Natl Cancer Inst. 1998;90(18):1371-1388.

53. Chlebowski RT, et al. Influence of estrogen plus progestin on breast cancer and mammography in healthy postmenopausal women: the Women's Health Initiative Randomized Trial. JAMA. 2003;289(24):3243-3253.

54. Dupont S, Krust A, Gansmuller A, Dierich A, Chambon P, Mark M. Effect of single and compound knockouts of estrogen receptors alpha (ERalpha) and beta (ERbeta) on mouse reproductive phenotypes. Development. 2000;127(19):4277-4291.

55. Dunaif A, Wu X, Lee A, Diamanti-Kandarakis E. Defects in insulin receptor signaling in vivo in the polycystic ovary syndrome (PCOS). Am J Physiol Endocrinol Metab. 2001;281(2):E392-E399.

56. Corbould A, Zhao H, Mirzoeva S, Aird F, Dunaif A. Enhanced mitogenic signaling in skeletal muscle of women with polycystic ovary syndrome. Diabetes. 2006;55(3):751-759

57. Hosoi T, Kawagishi T, Okuma Y, Tanaka J, Nomura $\mathrm{Y}$. Brain stem is a direct target for leptin's action in the central nervous system. Endocrinology. 2002; 143(9):3498-3504.

58. Paxinos G, Franklin K. The Mouse Brain In Stereotaxic Coordinates. New York, New York, USA: Academic Press; 1997.

59. Benoit SC, et al. Palmitic acid mediates hypothalamic insulin resistance by altering PKC-theta subcellular localization in rodents. J Clin Invest. 2009;119(9):2577-2589. 